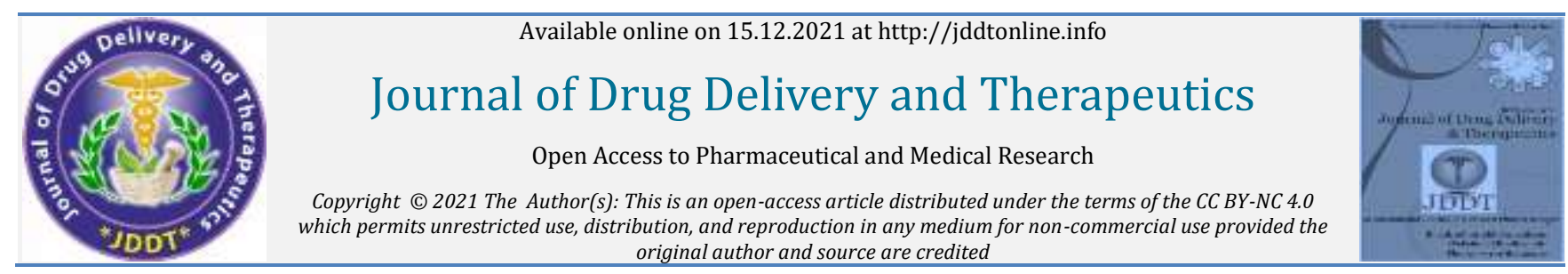
original author and source are credited

Research Article

\title{
A Comparative Study on Antioxidant and Cytotoxic Potentials of Methanol Extract of Jatropha curcas Seeds and Leaves
}

\author{
Sulaimon Lateef A.1, ${ }^{*}$, Ola-Mudathir Fausat K. ${ }^{2}$, Abdullahi Bunyamin A. ${ }^{1}$, Mukhtar Ahmad I. ${ }^{1}$, Obuotor Efere M. ${ }^{3}$ \\ ${ }^{1}$ Department of Chemical Sciences, Crescent University, Abeokuta, Ogun State, Nigeria \\ ${ }^{2}$ Department of Physical and Chemical Sciences, Elizade University, Ilara Mokin, Osun State, Nigeria \\ ${ }^{3}$ Department of Biochemistry, Obafemi Awolowo University, Ile-Ife, Osun State, Nigeria
}

Article Info:

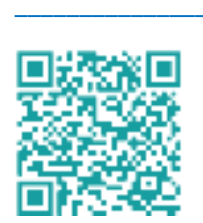

Article History:

Received 14 October 2021

Reviewed 30 November 2021

Accepted 06 December 2021

Published 15 December 2021

\section{Cite this article as:}

Sulaimon LA, Ola-Mudathir FK, Abdullahi BA, Mukhtar AI, Obuotor EM, A Comparative Study on Antioxidant and Cytotoxic Potentials of Methanol Extract of Jatropha curcas Seeds and Leaves, Journal of Drug Delivery and Therapeutics. 2021; 11(6-S):43-48

DOI: http://dx.doi.org/10.22270/jddt.v11i6-S.5220

*Address for Correspondence:

Sulaimon Lateef A., Department of Chemical Sciences, Crescent University, Abeokuta, Ogun State, Nigeria

\author{
Abstract
}

\begin{abstract}
Many medicinal plants have been reported to exhibit protective effects against many physiological diseases as a result of their phytochemical components which are effective antioxidants. This study was aimed at comparing the phenolic and flavonoids contents, antioxidant and cytotoxic activities of methanol extract of Jatropha curcas seeds and leaves. The cytotoxicity level of J. curcas was assessed using the brine shrimp lethality test (BSLT). The antioxidant activity was determined by 1,1-diphenyl-2-picrylhydrazyl (DPPH) radical scavenging activity, ferric reducing antioxidant power (FRAP), nitric oxide scavenging activities, 2, 2'azino-bis-(3 ethyl benzothiazoline-6-sulphonic acid (ABTS) + scavenging activities and total antioxidant capacity. The total flavonoids and total phenols content (TPC) were carried out using aluminum chloride and Folin-Ciocalteu assay respectively. The results showed that $J$. curcas leaves have significant higher phenolic and flavonoids contents than the seeds. The total antioxidant capacity and FRAP were also significantly higher in the leaves than the seeds of $J$. curcas. Furthermore, the DPPH, ABTS and Nitric oxide scavenging activities were significantly higher in the leaves than the seeds. The J. curcas leaves have a higher $\mathrm{LD}_{50}$ than the seeds. In conclusion, this study suggests the antioxidant potency as well as the safety of the crude methanol extract of the leaves of $J$. curcas over the seeds.
\end{abstract}

Keywords: Jatropha curcas, antioxidant, cytotoxicity, flavonoids, brine shrimp lethality test, total phenolic compounds

\section{INTRODUCTION}

The prevalence of many chronic health complications is continually increasing in the entire world. These health complications include diabetes, aging, cancer and cardiovascular diseases. Oxidative stress which is usually caused by the presence of prooxidants, have been implicated in the pathogenesis of these diseased states ${ }^{1}$. Prooxidants are any endobiotics or xenobiotics (e .g drugs and transition metals) that induce oxidative stress either by generation of free radicals such as reactive oxygen species (ROS) or by inhibiting antioxidant systems. Free radicals are continuously generated in the cell as a result of normal human metabolism in the mitochondria 2 . Antioxidant defense counter the effect of free radicals and thus prevent oxidative stress. Oxidative stress can therefore be referred to as a condition where the amount of free radicals in the body has exceeded the antioxidants in the body system or when the limit of body's ability to neutralize the free radicals is exceeded. The ROS produced in the tissues can inflict direct damage to macromolecules, such as lipids, nucleic acids, and proteins resulting in cell damage 3. Endogenous and exogenous antioxidants are required to scavenge free radicals and to convert ROS to more stable molecules, such as water and oxygen. These antioxidants include high molecular weight (SOD, GPx, Catalase, albumin, transferrin) and low molecular weight substances (ascorbic acid, lipoic acid, glutathione, vitamin E, flavonoids) 4 .

Jatropha curcas L. is a drought-resistant shrub in Euphorbiaceae family. It is widespread in tropical and subtropical regions of Southeast Africa, Central and Latin America etc. 5 . Previous studies have shown that methanol extract of J. curcas root contained various phenolic compounds such as flavonoids and saponins compounds and exhibit high antioxidant, anticancer, and anti-inflammatory activities ${ }^{6}$. The leaves of $J$. curcas also contain apigenin, vitexin and isovitexin, they are therefore used for treatment of malaria, rheumatic and muscular pains ${ }^{7}$. They also possess antibacterial activity against Staphylococcus aureus, Escherichia and Pseudomonas aeruginosa ${ }^{8}$. Fagbenro-Beyioku et al. ${ }^{9}$ has also shown the anti-parasitic activity of sap and crushed leaves of Jatropha curcas. The seed oil, latex and leaf of Jatropha plants have been used to treat skin infections such as eczema, itches, carbuncles and mouth blisters. The seed oil of Jatropha species has been shown to exhibit purgative effect. 
Current research is directed towards finding naturally occurring antioxidants of plant origin. Many natural plant seeds used for nutrition and as therapeutic agents have been reported to show some toxicological effects or even cause instant death after use. Jatropha curcas seeds and leaves although possess therapeutic effects, their toxicity effects have also been reported. Thus, one of the major limitations of the use of the tropical plant materials as therapeutic agents is their toxicity. The cytotoxic/cytostatic activities of root extracts and chemical constituents of Jatropha species against certain cancer cell lines has also been reported 10 .

The therapeutic use of Jatropha curcas seeds and leaves need to be evaluated and compared in relation to their antioxidant and cytotoxic effect to determine the preference of use of seeds and leaves in diseased state. Therefore this research compared the antioxidant potentials of Jatropha curcas seeds and leaves by using various antioxidant assays as well as the cytotoxicity of the seeds and leaves using brine shrimp bioassay.

\section{MATERIALS AND METHODS}

\section{Plant Materials}

The fresh seeds and leaves of Jatropha curcas were collected at Crescent University campus, Abeokuta, Ogun state, Nigeria. The seeds were identified by the Department of Botany, Obafemi Awolowo University, Ile-Ife, Osun State, Nigeria. The seeds and leaves were then dried at room temperature and grinded into fine powder.

\section{Chemicals}

The chemicals used in this study include methanol, distilled water, L-ascorbic acid, and 2,2-diphenyl-1-picrylhydrazyl (DPPH.), sodium nitroprusside (SNP), sodium nitrite, sulphanilamide, phosphate buffer saline (PBS), phosphoric acid, potassium persulphate, Griess reagent, glacial acetic acid, ethanol, trolox standard solution, sodium hydroxide $(\mathrm{NaOH})$, ferric chloride $\left(\mathrm{FeCl}_{3}\right)$, naphthylethylene diamine dihydrochloride (NED), sodium nitrite, aluminiumtrichloride, Folinciocalteu reagent (FCR), TPTZ (2,4,6-Tris(2-pyridyl) 3triazine), ferric tripyridyltriazine, sulphuric acid, sodium phosphate, ammonium molybdate, sodium carbonate, gallic acid, quercetin, hydrochloric acid, iron (III) ammonium sulphate, DMSO (Dimethyl sulfoxide), potassium dichromate. All the chemicals used, including the solvents were of analytical grade.

\section{Preparation of Jatropha curcas Seeds and Leaves Metha- nol Extracts}

Twenty gram $(20 \mathrm{~g})$ of grinded seeds and leaves of $J$. curcas were weighed and added to $100 \mathrm{ml}$ of $80 \%$ methanol. The solution was stirred for 24 hours by using a magnetic stirrer. The solution was filtered using the filter paper (Whatman filter paper number 1). The filtrate was concentrated using a rotary evaporator set at $45^{\circ} \mathrm{C}$. The concentrated filtrate was poured into a petridish and exposed to air to dry.

\section{2, 2-diphenyl-1-picrylhydrazyl (DPPH) radical scaveng- ing assay}

The radical scavenging ability was determined using the stable radical DPPH (2, 2-diphenyl-1-picrylhydrazyl hydrate) as described by 11 . To $150 \mu \mathrm{l}$ of each of the extract solution at varying concentration in microplate was added $150 \mu \mathrm{l}$ of 0.3 $\mathrm{mM}$ DPPH solution and incubated in the dark at $37^{\circ} \mathrm{C}$ for 30 minutes. The absorbance was taken at $510 \mathrm{~nm}$. Ascorbic acid was used as standard. The scavenging ability of the plant extract was calculated using this equation: DPPH Scavenging activity $(\%)=[($ Abs control - Abssample $)] /($ Abs control $)] \times 100$. Where $\mathrm{Abs}_{\text {control }}$ is the absorbance of $\mathrm{DPPH}+$ methanol; $\mathrm{Ab}$ -
Ssample is the absorbance of DPPH radical + sample extract or standard. The assays were carried out in triplicates and the results are expressed as mean \pm standard error.

\section{2, 2'-azino-bis-(3 ethylbenzothiazoline-6-sulphonic Acid) (ABTS) scavenging assay}

The method of 12 was adopted for the determination of ABTS activity of the plant extracts. The stock solutions were of 7 $\mathrm{mM}$ ABTS+ and $2.4 \mathrm{mM}$ potassium persulphate solutions. The working solution was then prepared by mixing the two stock solutions in equal quantities and allowing them to react for $12 \mathrm{~h}$ at room temperature in the dark. The solution was diluted with $70 \%$ ethanol to an absorbance at $0.75 \pm$ $0.02734 \mathrm{~nm} .1 \mathrm{ml}$ of varying concentration of the extracts and standard solutions (Trolox), were allowed to react with $1 \mathrm{ml}$ of ABTS+ solution, and the absorbance was measured at $734 \mathrm{~nm}$ after 20 minutes using spectrophotometer. The ABTS+ scavenging capacity of the extract was compared with that of Trolox and percentage inhibition calculated as ABTS radical scavenging activity $(\%)=\left[\mathrm{Abs}_{\text {control }}-\mathrm{Ab}\right.$ S sample $) /\left(\right.$ Abs $\left.\left._{\text {control }}\right)\right] \times 100$

Where $\mathrm{Abs}_{\text {control }}$ was the absorbance of ABTS+ radical + methanol; Abs sample is the absorbance of ABTS+ radical + sample extract or trolox. The assays were carried out in triplicate and the results are expressed as mean \pm standard error of mean

\section{Nitric Oxide Scavenging Activity}

The method of 13 was used to determine the nitric oxide radical scavenging activity of extracts of $J$. curcas seeds and leaves. A volume of $0.9 \mathrm{~mL}$ of $2.5 \mathrm{mM}$ sodium nitroprusside prepared in phosphate buffer saline $(\mathrm{pH} 7.4)$ was mixed with $0.1 \mathrm{ml}$ varying concentrations of plant extracts and varying concentration of ascorbic acid as standard. The mixture was incubated under illuminated using fluorescence light at room temperature for 150 minutes. After incubation, $0.5 \mathrm{~mL}$ of $1 \%$ sulphanilic acid in 5\% phosphoric acid was added and incubated in the dark for 10 minutes, followed by addition of 0.5 $\mathrm{ml}$ of $0.1 \% \mathrm{~N}-1$ - napthyl ethylene diamine dihydrochloride (Griess reagents). The absorbance was then measured at 540 $\mathrm{nm}$. The amount of nitric oxide radical was calculated using the equation:

$\%$ Inhibition of nitric oxide radical scavenging activity =

$\left[\left(\right.\right.$ Abs $_{\text {control- }}$ AbsSample $\left.)\right] /\left(\right.$ Abs $\left.\left._{\text {control }}\right)\right] \times 100$.

The assays were carried out in triplicate and the results are expressed as mean \pm standard error of mean

\section{Determination of Ferric Reducing Antioxidant Power (FRAP)}

The antioxidant activity of samples was determined by 14 FRAP reagent was prepared by mixing 2,4,6-Tris(2-pyridyl) 3 -triazine (TPTZ) ( 0.003 of TPTZ in $1 \mathrm{ml}$ of $40 \mathrm{mM} \mathrm{HCl}), 300$ $\mathrm{mM}$ acetate buffer with $\mathrm{pH} 3.4$ and $20 \mathrm{mM}$ ferric chloride in the ratio $1: 10: 1$. To $25 \mu \mathrm{L}$ of $1 \mathrm{mg} / \mathrm{ml}$ of each extract and 25 $\mu \mathrm{L}$ of standards with varying concentrations of ascorbic acid was added $300 \mu \mathrm{L}$ of FRAP reagent. These were incubated at $37^{\circ} \mathrm{C}$ for 90 minutes and absorbance was measured at 593 $\mathrm{nm}$. The higher absorbance of the reaction mixture indicates strong reducing power of the plant extract. The assays were carried out in triplicate and the results are expressed as mean \pm standard error of mean. The reducing power was expressed as equivalent concentration (EC) which is defined as the concentration of antioxidant that gave a ferric reducing ability equivalent to that of the ascorbic acid standard. 


\section{Total Antioxidant Capacity (TAC) Assay}

This method is based on the reduction of Molybdenum (VI) to Molybdenum (V) by the extract and the subsequent formation of a green phosphate/Molybdenum (V) complex at an acidic $\mathrm{pH}{ }^{15}$. To $0.1 \mathrm{ml}$ of $0.1 \mathrm{mg} / \mathrm{ml}$ of the extracts as well as varying concentrations of standard solution of ascorbic acid was added $1 \mathrm{ml}$ of TAC reagent which consisted of $0.6 \mathrm{M}$ sulphuric acid, $28 \mathrm{mM}$ sodium phosphate and $4 \mathrm{mM}$ ammonium molybdate. The tubes containing the reacting mixture were incubated in a water bath at $95^{\circ} \mathrm{C}$ for 90 mins. The mixture was then allowed to stand and cool to room temperature and the absorbance measured at $695 \mathrm{~nm}$. The assays were carried out in triplicate and antioxidant activities of the extracts were expressed as an ascorbic acid equivalent.

\section{Determination of total flavonoids content}

Total flavonoids content was determined based on the aluminum chloride colorimetric assay method as described by 16 using quercetin as a standard. $25 \mu \mathrm{L}$ of samples $(1 \mathrm{mg} / \mathrm{ml})$ solution in methanol as well as varying concentrations of standard solutions of ascorbic acid were mixed with $25 \mu \mathrm{L}$ of $5 \%$ NaNO2 and $100 \mu \mathrm{L}$ of distilled water was added in microtiter plates. After incubation at room temperature for 5 minutes, $25 \mu \mathrm{L}$ of $10 \% \mathrm{AlCl}_{3}$ was added to the mixtures, followed by addition of $50 \mu \mathrm{L}$ of $1 \mathrm{M} \mathrm{NaOH}$. $25 \mu \mathrm{l}$ of distilled water is then added into the micro plate to make the overall volume $250 \mu \mathrm{L}$. The absorbance was taken at $510 \mathrm{~nm}$. The assays were carried out in triplicate. The total flavonoids in each plant extract were determined as quercetin equivalents per gram extract ( $\mathrm{mg} \mathrm{QE} / \mathrm{g}$ extract).

\section{Determination of total phenol Content}

The total phenols content of the extracts was determined by Folin-Ciocalteu method as reported by ${ }^{17}$ using the Folin Ciocalteu's phenol reagent as the oxidizing reagent. To $100 \mu \mathrm{L}$ of $0.1 \mathrm{mg} / \mathrm{mL}$ of the extract and $100 \mu \mathrm{L}$ of varying concentrations of standard solutions, was mixed $200 \mu \mathrm{L}$ of $20 \%$ FolinCiocalteu reagent. After 5 minutes, $1 \mathrm{ml}$ of $7 \%$ sodium carbonate $(75 \% \mathrm{w} / \mathrm{v})$ and $300 \mu \mathrm{L}$ of distilled water were added. The mixtures were vortexed for 15 seconds and incubated at room temperature for 90 minutes for color appearance. The absorbance was measured at $750 \mathrm{~nm}$. The amount of total phenolic content was expressed as mg gallic acid equivalent per gram dry weight extract (mg GAE/g extract). The assays were carried out in triplicate. The results were expressed as mg gallic acid equivalent per gram dry weight extract (mg GAE/g extract).

\section{Cytotoxicity bioassay}

\section{Test sample preparation for brine shrimp bioassay}

Test sample was dissolved in DMSO (Dimethyl sulfoxide) to obtain stock solution of $1 \mathrm{mg} / \mathrm{mL}$ concentration. The final concentration of DMSO in the assay volume was kept at $2 \%$ to prevent possible false effects originating from DMSO toxicity. Artificial seawater was used as negative control and potassium dichromate was used as the reference standard for the cytotoxicity assay.

\section{Hatching of Brine shrimp cysts}

The cysts were hatched in a hatching tank containing artificial seawater made through dissolving a commercial marine salt $(2 \%)$ in $\mathrm{RO}$ water (mineral water). The tank was well aerated with the aid of an air pump and the proper light source (1000-4000 lux) was also provided. The nauplii were hatched within $24 \mathrm{~h}$.

\section{Brine shrimp lethality test}

The toxicity of the extracts was tested at varying concentrations of $31.25,62.5,125,250$ and $500 \mu \mathrm{g} / \mathrm{mL}$ in sea water containing 2\% DMSO (v/v). Ten nauplii were used in each test. Two replications were used for each concentration. A parallel series of tests with the standard potassium dichromate solution (concentration $=20,40,60,80,100 \mu \mathrm{g}$ ) were tested and the blank control was included. After $24 \mathrm{~h}$, survivors were counted. Using probit analysis, the lethality concentration (LD50) was assessed at 95\% confidence intervals. Cytotoxicity was considered significant if the $\mathrm{LD}_{50}$ value was less than $20-30 \mu \mathrm{g} / \mathrm{mL}$

\section{RESULTS AND DISCUSSION}

Excess production of ROS leads to oxidative stress, which can cause a number of diseases. In such conditions dietary intake of antioxidant compounds are needed in assisting the body to neutralize the free radicals to remove the harmful effects of oxidative stress. Fruits, vegetables, grains and medicinal plants contain phenolic compounds such as flavonoids, anthocyanins, coumarins which possess antioxidant activity. Their free radicals scavenging activities is due to their ability to donate hydrogen atom and transfer electron to reduce radicals. DPPH radical scavenging activity, FRAP molybdate ion reduction assays, ABTS radical scavenging assay, nitric oxide scavenging activity were employed in this assay to compare the antioxidant activity of the $J$. curcas seeds and leaves. The total phenolic, total antioxidant capacity, total flavonoids were also determined.

The ability of an antioxidant component in the extracts to scavenge DPPH was evaluated on the basis of their $\mathrm{IC}_{50}$ value, defined as the concentration of sample to decrease the absorbance at $517 \mathrm{~nm}$ of DPPH solution to half of its initial value. A lower $\mathrm{IC}_{50}$ value indicates a strong ability of the component in the extracts to act as DPPH scavengers, i.e. a higher ability to donate hydrogen to DPPH to form the non-radical form DPPH and vice-versa ${ }^{18}$. From the results obtained in this study, the crude methanol extract of $J$. curcas leaf has a lower IC 50 than the seed with values of $0.171 \pm 0.003 \mathrm{mg} / \mathrm{ml}$ and $5.560 \pm 0.210 \mathrm{mg} / \mathrm{mL}$ respectively (Table 1 ), while the $\mathrm{IC}_{50}$ for both the seed and leaf were higher than the value obtained for the standard, vitamin C $\left(\mathrm{IC}_{50}=0.02 \pm 0.003\right.$ ). This indicates that the J. curcas leaves are more capable than the seed in donating hydrogen to a free radical in order to remove abnormal electron which is responsible for radical's reactivity and thus an indication of stronger antioxidant effect of the leaves. Similar results was obtained for the J.curcas leaves by ${ }^{19}$, which showed a low $\mathrm{IC}_{50}$ compared to the fruits of J. curcas, but higher than the value for vitamin C. The seeds of $J$. curcas have also been reported to exhibit DPPH radical scavenging activity 20.

ABTS radical cation (ABTS $\left.{ }^{\bullet}\right)$ generated by oxidation of ABTS with potassium persulphate is converted to its nonradical form in the presence of antioxidants by the donation of hydrogen atom to the radical, hence, the ABTS radical cation scavenging activity reflects hydrogen atom donating ability of the antioxidants. As indicated in table 1, the IC50 obtained for ABTS radical cation scavenging activity for both the leaves and seeds of $J$. curcas were higher than that obtained for the standard (Trolox) which has a value of $7.697 \pm$ 1.433. The leaves exhibited an $\mathrm{IC}_{50}$ of $10.098 \pm 1.368$ which is lower than the value obtained for the seeds $(15.50 \pm 2.59)$. These results also reflect a higher ability of the leaves to scavenge free radicals than the seed 21 . Papalia et al., ${ }^{22}$ also reported that $J$. curcas leaves exhibited both DPPH and ABTS radical cation scavenging activities. 
The nitric oxide scavenging property of J. curcas leaves and seeds compared with reference ascorbic acid is expressed in table 1 , with the leaves of $J$. curcas exhibiting a lower $\mathrm{IC}_{50}$ value $(4.48 \pm 0.008)$ than that of the seeds ( $\mathrm{IC}_{50}$ value of $12.689 \pm 0.55$ ). However, both the leaves and seeds show $\mathrm{IC}_{50}$ values that are higher than that obtained for ascorbic acids $(0.056 \pm 0.002)$. Igbinosa et al. ${ }^{8}$ showed that the stem bark of $J$. curcas possess DPPH, ABTS ${ }^{\bullet}$ and nitric oxide radical scavenging activity. The result of the nitric oxide scavenging assay in this study is in line with those obtained for DPPH and ABTS radical cation scavenging activity, indicating that free radical scavenging activity of the leaves and seed extracts may be attributed to their proton donating ability. The free radical scavenging activity is also higher in the leaves than in the seeds of $J$. curcas. These results suggest that the plant extracts contain compounds that are capable of donating hydrogen to a free radical in order to remove abnormal electron which is responsible for radical's reactivity. These findings imply that, radical scavenging activity of the extracts may be attributed to their proton donating ability.

Phenolic compounds, example of which is flavonoids, are one of the most powerful metabolites in plants that possess antioxidant activity and various other biological activities such as, anti-inflammatory, antimicrobial, have been attributed to them ${ }^{23}$. The result of this study revealed the presence of phenol and flavonoids in the leaves and seeds of J.curcas. As shown in table 2 , the leaves possess higher phenolic and flavonoids content $(49.89 \pm 2.414 ; 151 \pm 10.89$ respectively), than the seeds $(7.923 \pm 1.273 ; 13.00 \pm 0.3471$ respectively). The presence of flavonoids have been reported in the leaves of $J$. curcas ${ }^{24}$, that of phenolic compounds was reported in root, seed and leaf of J. curcas 6 .

DPPH radical, ABTS ${ }^{\bullet+}$ and nitric oxide scavenging activity is used to determine hydrogen donating ability of a compound, while the ferric-reducing power of a compound is used to determine the electron donating capacity of antioxidants. These properties are the main characteristics of phenolic compounds 25 . The above mentioned properties which were exhibited higher in the leaves of $J$. curcas could be as a result of the higher phenolic and flavonoids content of the leaves of J. curcas compared to the seeds J. curcas. Polyphenols scavenge ROS effectively and chelate metals. The leaves of J. curcas may therefore possess higher antioxidant activity than the seeds of $J$. curcas. This is in line with the findings of 26 , who reported that increasing antioxidant activity correlate with total phenolic content of J. curcas fruits.

The FRAP assay measures the ability of antioxidant to donate electron for the reduction of $\left[\mathrm{Fe}^{3+}(\mathrm{CN}) 6\right]^{3-}$ to $\left[\mathrm{Fe}^{2+}(\mathrm{CN}){ }^{6}\right]^{4-}$ 27 i.e. the ferric iron $\left(\mathrm{Fe}^{3+}\right)$ of iron potassium cyanide was reduced to bivalent iron ion $\left(\mathrm{Fe}^{2+}\right)$. As indicated in table 3, the leaves and seeds extracts of $J$. curcas yielded the FRAP values of $151.4 \pm 4.829$ and $2.67 \pm 0.6094 \mathrm{mg} \mathrm{AAE} / \mathrm{g}$ of sample respectively. Iron is one of the main elements involved in the formation of radical species. This study that the generations of the free radicals by iron may be prevented more by leaves than the seeds. Huang et. al., ${ }^{28}$ showed that the leaves of $J$. curcas possess FRAP property. The higher value for leaf extract is an indication of higher reducing power of the leaves and thus a higher ability to transfer electrons, than does the seeds. Thus the leaves exhibit a stronger antioxidant effect than the seed. The results showed a good correlations between the electron and hydrogen donating ability of the extracts in terms of the DPPH radical, ABTS •+ and Nitric oxide scavenging activity.

The total antioxidant capacity determined by phosphomolybdate method based on the reduction of Mo (VI) to Mo (V) measures the total antioxidant capacity of the extracts both in terms of hydrogen and electron donating ability. This is a reflection of polyphenols in the extracts. As indicated in table 3 the total antioxidant capacity of the leaves of J. curcas (59.06 \pm 9.613$)$ is higher than that obtained for the seeds $(7.697 \pm 1.433)$. This result may be due to the higher phenolic and flavonoids content obtained for the leaves compared to the seeds as the antioxidant activities of plant extracts are often attributed to their total phenolic and flavonoids contents ${ }^{29}$. This result is also consistent with the above results of DPPH radical, ABTS •+, Nitric oxide scavenging activity and FRAP assay, indicating that higher total antioxidant capacity of the leaves of $J$. curcas is a reflection of its reducing capacity. Chua et al., ${ }^{30}$ also attributed the reducing ability of plants to antioxidant capacity.

The presence of phenolic compounds in J. curcas leaves and seeds may be responsible for their antioxidant activities. Thus, J. curcas leaves and seeds could reduce oxidative stress which has been implicated in the pathogenesis of many disease states. From the results above, it has been shown that the leaves are more effective than the seeds. Papalia et. al., 22 also reported that the compounds present in the methanol extract of Jatropha leaves are able to reduce the formation of malondialdehyde, a marker of oxidative stress.

In this study the cytotoxic potential of methanol extracts of $J$. curcas leaves and seeds were investigated. BSLT assay was used to determine the cytotoxicity of these extracts. The brine shrimp lethality assay has been proven to be a convenient system for monitoring biological activities of natural products. From the results indicated in table 4 , the $\mathrm{LD}_{50}$ value for the $J$. curcas leaves is $112.963 \mu \mathrm{g} / \mathrm{mL}$ while that for the seeds is $22.143 \mu \mathrm{g} / \mathrm{mL}$ and the standard $\left(\mathrm{K}_{2} \mathrm{Cr}_{2} \mathrm{O}_{7}\right)$ is $5.653 \mu \mathrm{g} / \mathrm{mL}$. The degree of lethality was directly proportional to the concentration of the extract. The $\mathrm{LD}_{50}$ for both the leaves and seeds are much higher than that obtained for $\mathrm{K}_{2} \mathrm{Cr}_{2} \mathrm{O}_{7}$. Furthermore, Syahmi et. al., ${ }^{31}$ reported that $\mathrm{LD}_{50}$ value of less than $1000 \mu \mathrm{g} / \mathrm{mL}$ is considered toxic while $\mathrm{LD}_{50}$ value of greater than $1000 \mu \mathrm{g} / \mathrm{mL}$ is non-toxic. It therefore implies that, although the extracts of the leaves and seeds of the J. curcas may be toxic, the toxicity is much lower in the leaves.

The brine shrimp test represents a rapid and simple bioassay for testing plant extract lethality which in most cases correlates reasonably well with cytotoxic and anti-tumor properties ${ }^{32}$. This study has shown that J. curcas leaf is less toxic than the seeds. This result is consistent with other studies that reported the extract from the plant of $J$. curcas to be highly active against tumor cells, L5178y mouse lymphoma cells, and HeLa human cervix carcinoma cells, but with a low effect on the neuronal cell line PC12. Patil et. al., ${ }^{24}$ also suggested that methanol extract of $J$. curcas leaf possesses minimal cytotoxic, but it prevents binding of hemagglutinin to cell receptors leading to inhibition of infection of influenza virus. Thus, owing to its lower cytotoxicity compared to the seeds, J. curcas leaf could be more important for use as antimicrobi$\mathrm{al}$, anti-cancer and anti-viral. 
Table 1: DPPH and Nitric Oxide Assay of the Jatropha curcas seeds and leaves

\begin{tabular}{llll}
\hline Plant & $\begin{array}{l}\text { DPPH free radical } \\
\text { activity } \\
\mathrm{IC}_{50}[\mathrm{mg} / \mathrm{ml}]\end{array}$ & $\begin{array}{l}\text { Nitric Oxide scavenging } \\
\text { activity } \\
\mathrm{IC}_{50}[\mathrm{mg} / \mathrm{ml}]\end{array}$ & $\begin{array}{l}\text { ABTS+ radical scavenging } \\
\text { activity } \\
\text { IC } 50[\mathrm{mg} / \mathrm{ml}]\end{array}$ \\
\hline Jatropha curcas seeds & $5.66 \pm 0.21$ & $12.689 \pm 0.55$ & $15.50 \pm 2.59$ \\
Jatropha curcas leaves & $0.1712 \pm 0.0033 \mathbf{a}$ & $4.4804 \pm 0.007 \mathbf{a}$ & $10.098 \pm 1.386 \mathbf{a}$ \\
Ascorbic Acids & $0.0267 \pm 0.0029 \mathbf{a b}$ & $0.056 \pm 0.002 \mathbf{a b}$ & - \\
Trolox & - & - & $7.697 \pm 1.433 \mathbf{a b}$ \\
\hline
\end{tabular}

Values are expressed as mean of triplicate determinations \pm standard error of mean

${ }^{\mathrm{a}} \mathrm{p}<0.05$ : significantly different from Jatropha curcas seed $\quad{ }^{\mathrm{b}} \mathrm{p}<0.05$ : significantly different from Jatropha curcas leaves

Table 2: Total phenolic and flavonoids contents of the Jatropha curcas seeds and leaves

\begin{tabular}{lll}
\hline Plant & $\begin{array}{l}\text { Total flavonoids } \\
\text { (mg gallic acid/g extract) }\end{array}$ & Total phenols (mg quercetin/g extract) \\
Jatropha curcas seeds & $13.00 \pm 0.3471$ & $7.923 \pm 1.273 \mathbf{a}$ \\
Jatropha curcas leaves & $151 \pm 10.89 \mathbf{a}$ & $49.89 \pm 2.414$ \\
\hline
\end{tabular}

Values are expressed as mean of triplicate determinations \pm standard error of mean.

${ }^{a} \mathrm{p}<0.05$ : significantly different from Jatropha curcas seeds

Table 3: Ferric Reducing Antioxidant Power Assay and Total Antioxidant Capacity Assay of Jatropha curcas seeds and leaves

\begin{tabular}{lll}
\hline Plant & $\begin{array}{l}\text { Ferric Reducing } \\
\text { Antioxidant Power assay } \\
\text { (mg Ascorbic Acid Equivalent/g) }\end{array}$ & Total Antioxidant assay \\
& (mg Ascorbic Acid Equivalent/g) \\
\hline Jatropha curcas seeds & $2.667 \pm 0.6094$ & $7.697 \pm 1.433$ \\
Jatropha curcas leaves & $151.4 \pm 4.829 \mathbf{a}$ & $59.06 \pm 9.613 \mathbf{a}$ \\
\hline
\end{tabular}

Values are expressed as mean of triplicate determinations \pm standard error of mean

${ }^{a} \mathrm{p}<0.05$ : significantly different from Jatropha curcas seed

Table 4: Cytotoxicity assay of Jatropha curcas seeds and leaves

\begin{tabular}{ll}
\hline Plant & LD 50 using Brine Shrimp Lethality Test (BSLT) \\
\hline Jatropha curcas seeds & $22.143 \mu \mathrm{g} / \mathrm{ml}$ \\
Jatropha curcas leaves & $112.963 \mu \mathrm{g} / \mathrm{ml}$ \\
STANDARD $\left(\mathrm{K}_{2} \mathrm{Cr}_{2} \mathrm{O}_{7}\right)$ & $5.653 \mu \mathrm{g} / \mathrm{ml}$ \\
\hline
\end{tabular}

\section{CONCLUSION}

From this investigation, J. curcas may have promising biological activities and can be further explored in research including antibacterial, antifungal and anticancer. Due to the cytotoxic and antioxidant activities possessed by the plant, it is more importantly recommended for external use. Thus, care should be taken in its use for herbal treatment involving internal usage. This study also reveals the potency and safety of the leaves over the seeds.

\section{Acknowledgements}

The authors appreciate the technical assistance of Mr. W. A. Idris and other technical staff of the Department of Chemical Sciences, College of Natural and Applied Sciences, Crescent University, Abeokuta.

\section{Conflicts of interest}

There are no conflicts of interest. 


\section{REFERENCES}

1. Valko M, Morris H, Mazúr M, Rapta P, Bilton RF, Oxygen free radical generating mechanisms in the colon: do the semiquinones of vitamin K play a role in the etiology of colon cancer?, Biochimica et Biophysica Acta, 2001; 1527(3):161-166 https://doi.org/10.1016/S0304-4165(01)00163-5

2. Inoue M, Sato EF, Nishikawa M, et al. Mitochondrial generation of reactive oxygen species and its role in aerobic life, Current Medicinal Chemistry, 2003; 10(23):2495-2505 https://doi.org/10.2174/0929867033456477

3. Cherubini A, Ruggiero C, Polidori MC, Mecocci P, Potential markers of oxidative stress in stroke, Free Radical Biology and Medicine, 2005; 39(7):841-852. https://doi.org/10.1016/j.freeradbiomed.2005.06.025

4. Ďuračková Z, Some current insights into oxidative stress, Physiological Research, 2010; 59(4):459-469. https://doi.org/10.33549/physiolres.931844

5. Divakara B, Upadhyaya HD, Wan SP, and Gowda LC, Biology and genetic improvement of Jatropha curcas L.: A review, Applied Energy, 2010; 87(3):732-742

https://doi.org/10.1016/j.apenergy.2009.07.013

6. Oskoueian E, Abdullah N, Saad WZ, Omar AR, Ahmad S, Kuan WB, et al., Antioxidant, anti-inflammatory and anticancer activities of methanolic extracts from Jatropha curcas L, J Med Plants Res., $2011 ; 5: 49-57$

7. Thomas 00, Re-examination of the antimicrobial activities of Xylopia aetiopica, Carica papaya, Ocimum gratissimum and Jatropha curcas, Fitoterapia, 1989; 60:147-155

8. Igbinosa, 00, Igbinosa EO, Aiyegoro OA, Antimicrobial activity and phytochemical screening of stem bark extracts from Jatropha curcas (Linn), Afr. J. Phar. Pharmacol, 2009; 3:58-62.

9. Fagbenro-Beyioku AF, Oyibo WA, Anuforom BC, Disinfectant/antiparaistic activities of Jatropha curcas, East Afr. Med. J., 1998; 75:508-511.

10. Aiyelaagbe 00, Adeniyi BA, Fatunsin OF, Arimah BD, In vitro antimicrobial activity and phytochemical analysis of Jatropha curcas roots, Int. J. Pharmacol., 2007; 3:106-110. https://doi.org/10.3923/ijp.2007.106.110

11. Brand-William W, Cuvelier ME, Berset CLWT, Use of a free radical method to evaluate antioxidant activity, LWT-Food science and Technology, 1995; 28(1):25-30 https://doi.org/10.1016/S00236438(95)80008-5

12. Re R, Pellegrini N, Proteggente A, Pannala A, Yang M, Rice-Evans C, Antioxidant activity applying an improved ABTS radical cation decolorization assay, Free Rad. Biol. Med., 1999; 26:1231-1237. https://doi.org/10.1016/S0891-5849(98)00315-3

13. Garrat DC, The Quantitative Analysis of Drugs, 3rd ed.; Chapman and Hall: Tokyo, Japan, 1964; 456-458.

14. Benzie IEF and Strain JJ, The ferric reducing ability of plasma (FRAP) as a measure of "antioxidant power", the FRAP assay. Anal Biochem, 1996; 239:70-76. https://doi.org/10.1006/abio.1996.0292

15. Prieto P, Pineda M, Anguilar M, Spectrophotometric quantitation of antioxidant capacity through the formation of a phosphomolybdenum complex: specific application to the determination of vitamin E, Analytical Biochemistry, 1999; 26(92):337-341. https://doi.org/10.1006/abio.1999.4019

16. Miliauskas G, Venskutonis PR, Van Beek TA, Screening of radical scavenging activity of some medicinal and aromatic plant extracts, Food chemistry, 2004; 85(2):231-237 https://doi.org/10.1016/j.foodchem.2003.05.007
17. Gülcin I, Antioxidant activity of caffeic acid (3, 4dihydroxycinnamic acid), Toxicology, 2006; 217:213-220 https://doi.org/10.1016/j.tox.2005.09.011

18. Duan X, Zhang W, Li X \& Wang B, Evaluation of antioxidant property of extract and fractions obtained from a red alga, Polysiphonia urceolata, Food Chemistry, 2006; 95(1):37-43. https://doi.org/10.1016/j.foodchem.2004.12.015

19. Rofida S, Antioxidant Activity of Jatropha curcas and Jatropha gossypifolia by DPPH method, Farmasains, 2015; 2(6):281-284.

20. Verma S, Gupta A, Kushwaha P, KhareV, Srivastava S, Rawat AKS, Phytochemical Evaluation and Antioxidant Study of Jatropha curcas Seeds, Pharmacognosy Journal, 2012; 14(29):50-54. https://doi.org/10.5530/pj.2012.29.8

21. Rajurkar NS and Hande SM, Estimation of Phytochemical Content and Antioxidant Activity of Some Selected Traditional Indian Medicinal Plants, Indian J Pharm Sci, 2011; 73(2):146-151 https://doi.org/10.4103/0250-474X.91574

22. Papalia T, Barreca D, and Panuccio RM, Assessment of Antioxidant and cyto-protective potential of Jatropha (Jatropha curcas) grown in Southern Italy, Int. J. Mol. Sci., 2017; 18:660 https://doi.org/10.3390/ijms18030660

23. Rice-Evans C, Miller NJ, Paganga G, Structure-antioxidant activity relationship of flavonoids and phenolic acids, Free Rad Biol Med., 1996; 20:933-56. https://doi.org/10.1016/08915849(95)02227-9

24. Patil D, Roy S, Dahake R, Rajopadhye S, Kothari S, Deshmukh R, and Chowdhary A, Evaluation of Jatropha curcas Linn. leaf extracts for its cytotoxicity and potential to inhibit hemagglutinin protein of influenza virus Indian, J Virol., 2013; 24(2):220-226. https://doi.org/10.1007/s13337-013-0154-z

25. Dorman HJD, Peltoketo A, Hiltunen R, Tikkanen MJ, Characterisation of the antioxidant properties of de-odourised aqueous extracts from selected Lamiaceae herbs, Food Chem, 2003; 83:25562. https://doi.org/10.1016/S0308-8146(03)00088-8

26. Saosoong K, Isarawat L, and Chalerm R, Antioxidant Activity of the Extracts from Jatropha curcas fruit and its Correlation with Total Phenolic Content, Oriental Journal of Chemistry, 2016; 32(2):1121-1127 https://doi.org/10.13005/ojc/320237

27. Nishaa S, Vishnupriya M, Sasikumar JM, Hephzibah PC, Christabel HP, Gopalakrishnan, VK, Antioxidant activity of ethanolic extract of Marantaar undinacea L tuberous rhizomes, Asian Journal of Pharmaceutical and Clinical Research, 2012; 5(4):85-88.

28. Huang Q, Guo Y, Fu R, Peng T, Zhang Y, Chen F, Antioxidant activity of flavonoids from leaves of Jatropha curcas, Science Asia, 2014; 40:193-197 https://doi.org/10.2306/scienceasia15131874.2014.40.193

29. Jang H-W, Ka M-H, Lee K-G, Antioxidant activity and characterization of volatile extracts of Capsicum annuum L. And Allium spp., Flavour and Fragrance Journal, 2008; 23(3):178-184. https://doi.org/10.1002/ffj.1872

30. Chua MT, Tung YT, and Chang ST, Antioxidant activities of ethanol extracts from the twigs of Cinnamomum osmophloeum, Bioresour Technol., 2008; 99:1918-1925 https://doi.org/10.1016/j.biortech.2007.03.020

31. Syahmi AR, VijayarathnaS, Sasidharan S, Latha LY, Kwan YP, Lau YL, Shin LN, Chen Y, Acute oral toxicity and brine shrimp lethality of Elaeis guineensis Jacq., (oil palm leaf) methanol extract, Molecules, 2010; 15(11):8111-21 https://doi.org/10.3390/molecules15118111

32. Chanda S, Baravalia Y, Brine shrimp cytotoxicity of Caesalpinia pulcherrima aerial parts, antimicrobial activity and characterisation of isolated active fractions, Nat Prod Res., 2011; 25(20):1955-64.

https://doi.org/10.1080/14786419.2010.530600 